Available online at GSC Online Press Directory

GSC Biological and Pharmaceutical Sciences

e-ISSN: 2581-3250, CODEN (USA): GBPSC2

Journal homepage: https://www.gsconlinepress.com/journals/gscbps

(RESEARCH ARTICLE)

\title{
Analysis of soil samples for its physicochemical parameters from Sangamner city
}

\author{
Sangita Changdeo Dandwate* \\ Department of Chemistry, Sahakar Maharshi Bhausaheb Santuji Thorat Arts, Commerce, Science College Sangamner, \\ Ahmednagar-422605(India).
}

Publication history: Received on 26 July 2020; revised on 07 August 2020; accepted on 12 August 2020

Article DOI: https://doi.org/10.30574/gscbps.2020.12.2.0243

\begin{abstract}
A physicochemical study of soil is based on various parameters like soil $\mathrm{pH}$, electrical conductivity (EC), organic carbon $(\mathrm{OC})$, available nitrogen (N), phosphorus (P), potassium (K), and micronutrients (Fe, Mn, Cu and Zn). Five representative samples were obtained and analyzed for its alkalinity content, $\mathrm{pH}$, electrical conductivity, organic carbon, sodium, potassium. A five soil samples were collected at a depth of 0-20 cm and analyzed for soils were neutral to slightly alkaline. The value of soil $\mathrm{pH}$ found to be 7.60 to 8.81 , conductivity was ranging from 0.50 to $0.73 \mathrm{dSm}^{-1}$, organic carbon was found to be 0.52 to $0.72 \%$, range of sodium was 0.52 to $0.97 \mathrm{meq} \%$ and potassium 125.31 to $630.15 \mathrm{~kg} / \mathrm{ha}$. Among the nutrients, available Nitrogen was found to be 140.01 to $252.68 \mathrm{~kg} / \mathrm{ha}$, Phosphorous was ranging from 15.11 to $54.13 \mathrm{~kg} / \mathrm{ha}$. This information will help the farmers to know amount of fertilizers to be added in soil to make production.
\end{abstract}

Keywords: Soil samples; physicochemical parameters; Sangamner city

\section{Introduction}

The soil test based nutrient management has emerged as a key issue in efforts to increase agriculture productivity. In recent years agriculture development has been changed from conventional and traditional farming method too more intensive practices using chemical fertilizers and pesticides with irrigation facilities. Continuous use of chemical fertilizers slowly changed soil properties; ultimately the production in long run is reduced. It has resulted in leaching of chemical into the surface and ground water [1-5]. Due to increasing demand for cash crops the practice of monoculture cropping pattern have further helped to deteriorate water as well as soil quality [6].

Soil and water are most important natural resources in cultivation of crops. The main objectives of the study were to assess the present status of soil. The physicochemical properties like soil pH, electrical conductivity (EC), organic carbon $(\mathrm{OC})$, available nitrogen $(\mathrm{N})$ and phosphorus $(\mathrm{P})$, potassium $(\mathrm{K})$ of soil samples from seven different sampling sites were analyzed $[7,8]$.

\section{Material and methods}

The quality test survey of the soil was conducted 2018. Five representative samples were collected in the depth of soil from different places of the city. Pravara and Mula Basin agriculture land is distributed in three parts, Irrigated land, non-irrigated land and Semi irrigated. Soil samples no. 1 to 5 from the eastern part of the city was collected for analysis. While collecting soil samples the upper layer of vegetation, surface litter, stones stubble if any were cleared away and then layer of soil immediately below $(0-20 \mathrm{~cm})$ was collected in polythene bag.

\footnotetext{
${ }^{*}$ Corresponding author: Dandwate Sangita Changdeo

Department of Chemistry, Sahakar Maharshi Bhausaheb Santuji Thorat Arts, Commerce, Science College Sangamner, Ahmednagar422605(India)
}

Copyright (C) 2020 Author(s) retain the copyright of this article. This article is published under the terms of the Creative Commons Attribution Liscense 4.0. 


\subsection{Physicochemical analysis}

The collected samples were analyzed for major physical and chemical soil quality parameter like soil $\mathrm{pH}$, electrical conductivity (EC), organic carbon (OC), available nitrogen (N), phosphorus (P), potassium (K) ) [9-15].

Table 1 Methods use for estimation of parameters

\begin{tabular}{lll}
\hline Sr. No. & Parameter & Method \\
\hline 1 & Colour & By viewing \\
2 & pH & Pontentiometry \\
3 & EC & Conductometry \\
4 & Organic carbon & Wet oxidation \\
5 & Available nitrogen & Alkaline permagnate \\
6 & Available Potassium & Flame photometry \\
7 & Available Phosphorous & Colorimetry \\
\hline
\end{tabular}

\section{Results and discussion}

The values of physicochemical parameters are presented in Table2 and figure 1 to 6 . Colour of the soil sample was observed visually and black and red colour.

Table 2 Physicochemical characteristics of study area

\begin{tabular}{llllllll}
\hline $\begin{array}{l}\text { Sample } \\
\text { no. }\end{array}$ & Colour & $\mathbf{p H}$ & $\begin{array}{l}\mathbf{E C} \\
\mathbf{d S m}^{-1}\end{array}$ & $\begin{array}{l}\text { Organic } \\
\text { carbon\% }\end{array}$ & $\begin{array}{l}\text { Available } \\
\text { nitrogen kg/ha }\end{array}$ & $\begin{array}{l}\text { Available } \\
\text { Phosphorous kg/ha }\end{array}$ & $\begin{array}{l}\text { Available } \\
\text { Potassium kg/ha }\end{array}$ \\
\hline 1 & Black & 8.55 & 0.73 & 0.62 & 241.0 & 31.15 & 125.31 \\
2 & Black & 8.81 & 0.58 & 0.71 & 252.40 & 54.13 & 321.20 \\
3 & Black & 7.60 & 0.55 & 0.72 & 252.68 & 50.09 & 248.15 \\
4 & Black & 7.92 & 0.50 & 0.65 & 230.51 & 28.12 & 630.15 \\
5 & Black & 8.10 & 0.60 & 0.52 & 140.01 & 15.11 & 128.15 \\
\hline
\end{tabular}

\section{1. $\mathrm{pH}$}

$\mathrm{pH}$ measure the relative conc. of hydrogen ion in the solution. The soil $\mathrm{pH}$ was determine by potentiometric $\mathrm{pH}$ meter using 1:2.5 soil water suspension ratio by Jackson. The value of $\mathrm{pH}$ showed lie in the alkaline side, $\mathrm{pH}$ of these soil is greater than 7 . Alkalinity is measure of saline or salt effected soil. If $\mathrm{pH}$ is less than 6.0 then soil type is acidic, the soil $\mathrm{pH}$ range from 6-8.5 its type is normal soil and greater than 8.5 then it is said to be alkaline type soil.

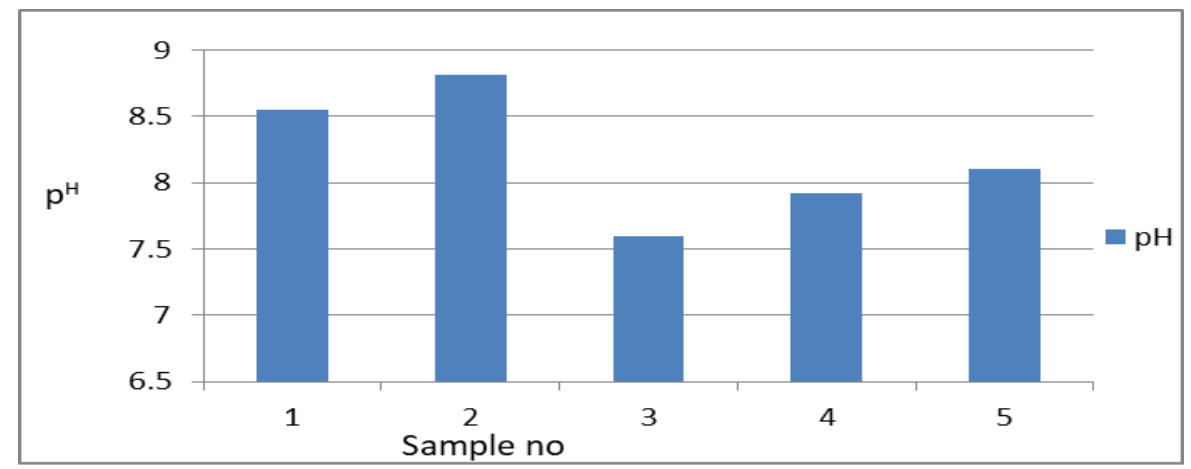

Figure 1 pH Indicator against sample no. 


\subsection{Electrical conductivity}

Electrical conductivity is very important property of the Soil. It indicates total soluble salts content of the soils. The value of conductivity is the measure of ions present in the soil sample. During this process the cations of the clay/colloidal matter are exchanged in equivalent quantities with the cations of soil and salt solutions. This process of exchanges of cation of soil and salt solution is known as cation exchange. Cations like $\mathrm{Ca}, \mathrm{Mg}, \mathrm{Na}, \mathrm{K}$ and anions such as $\mathrm{CO}_{3}$, $\mathrm{HCO}_{3}$, P04.The conductivity values can be vary with chemical properties of soil. If EC is less than 4 soil type is normal. A soil from study area EC values ranges from 0.50 to $0.73 \mathrm{dSm}-1$. All soil samples were lower EC values.

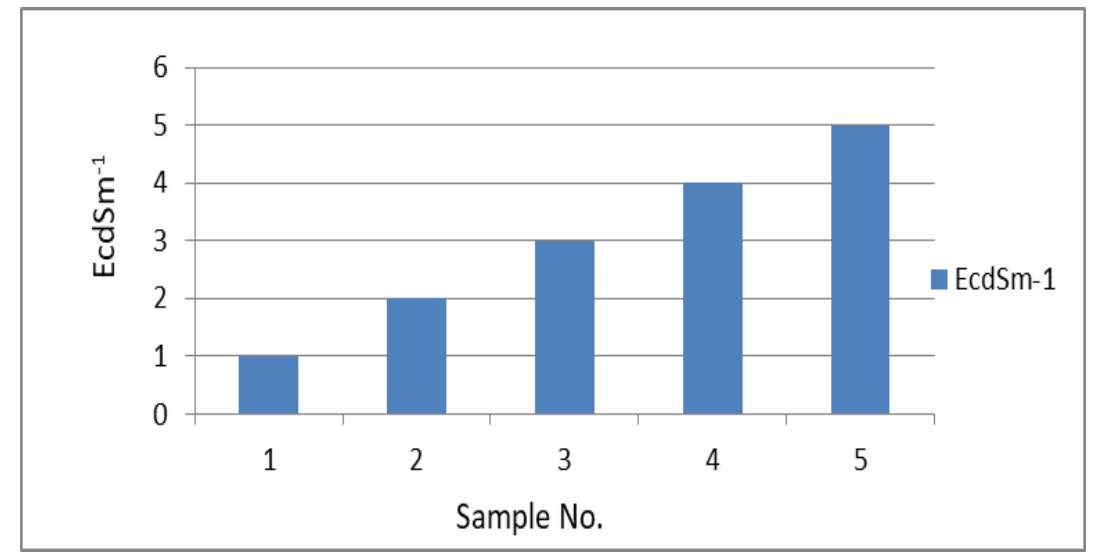

Figure 2 Electrical conductivity against sample no.

\subsection{Organic carbon}

The organic matter is an important of the soil that contributes to soil fertility. Soil organic carbon is the basis of soil fertility. It release nutrient for plant growth. , increasing soil organic carbon improves soil health and fertility [16]. The data given in table 2 . Organic carbon ranges from shows 0.52 to $0.72 \%$. Medium proportion of organic carbon.

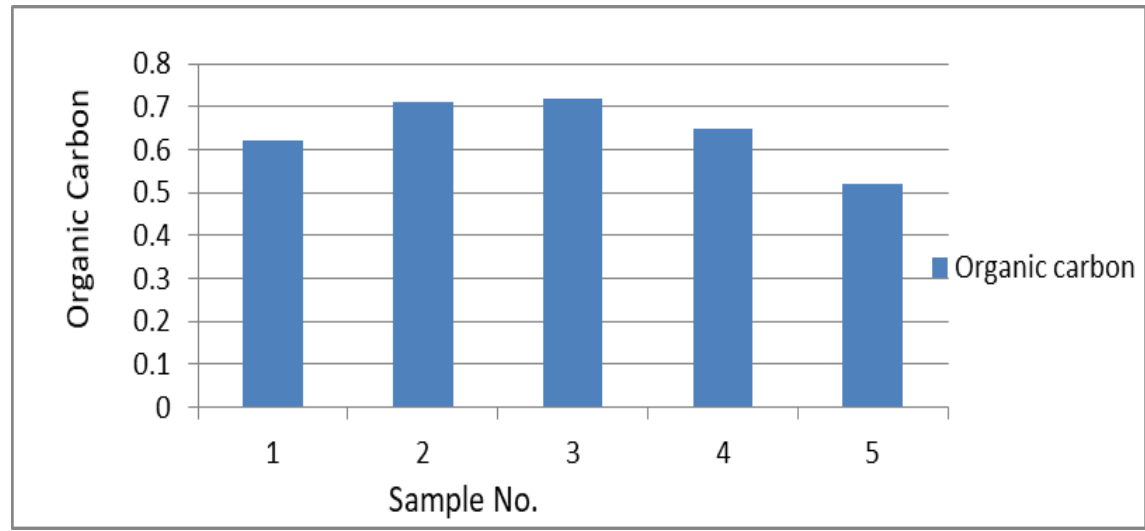

Figure 3 Organic carbon against sample no.

\subsection{Nitrogen}

The available nitrogen was determined by alkaline per magnet method [23] Nitrogen is an essential plant nutrient, for growth of plant canopy. Deficiency of nitrogen shows stunted growth development of yellowish green leaves and also deduces protein content and yields. Nitrogen is low in all soil samples. 


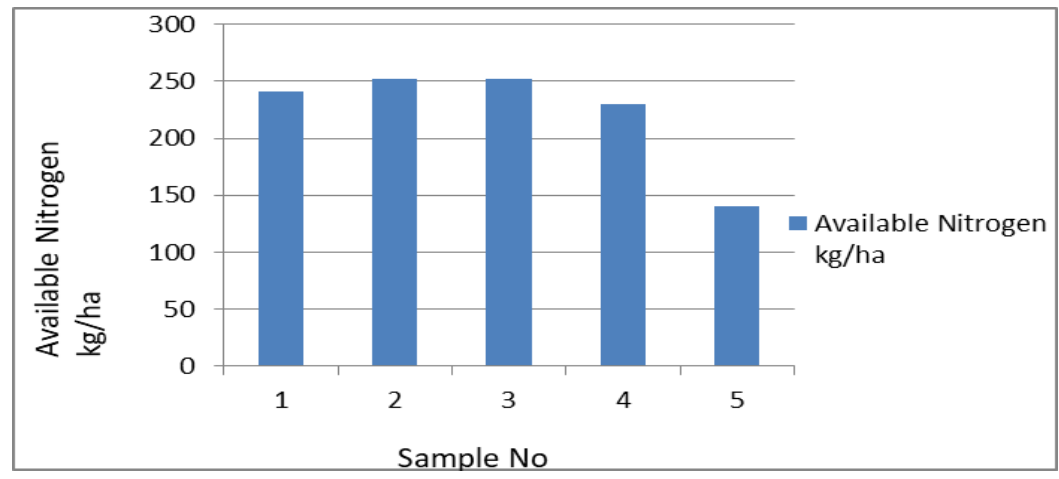

Figure 4 Fertility Status of study area

\subsection{Phosphorous}

Phosphorous is called the master key element in soil quality. It is a most important element in every living cell. It is essential for growth, cell division root growth and elongation seed and fruity development and early ripening [17]. Also it helps in energy storage and transfer. In study area phosphorous ranges 15.11 to $54.13 \mathrm{~kg} / \mathrm{ha}$.

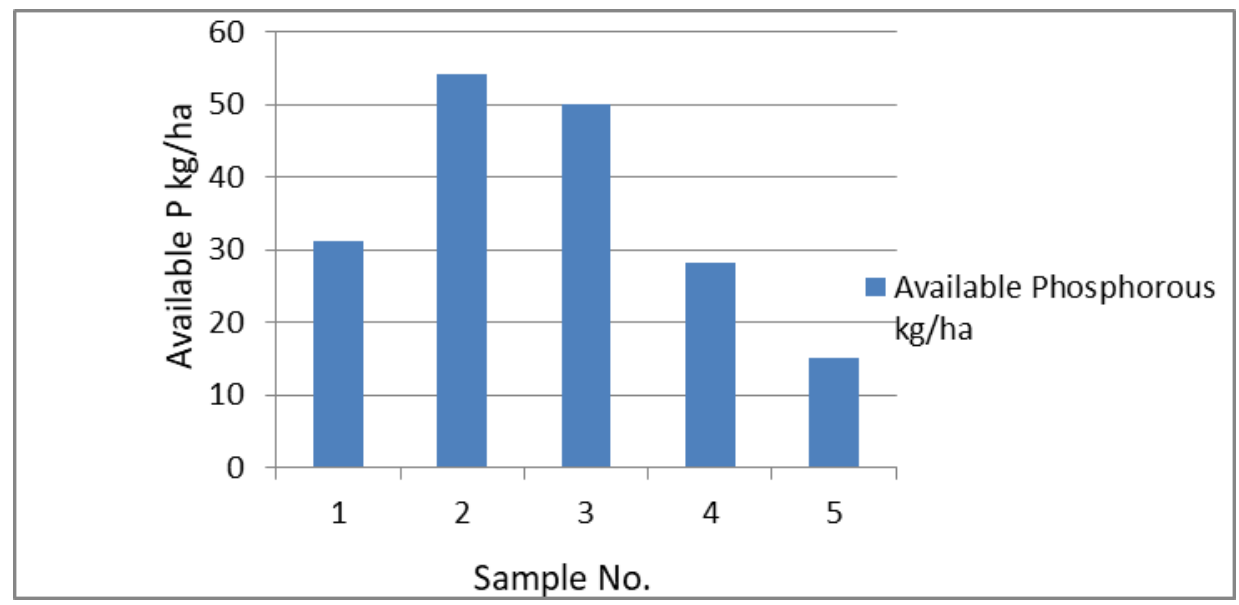

Figure 5 Fertility Status of study area

\subsection{Potassium}

Potassium plays an important role in different physiological processes of plants. Potassium is major nutrient for the production of superior quality crop. Its main role is catalytic in nature. Available potassium content ranges from 125.31 to $630.15 \mathrm{~kg} / \mathrm{ha}$. Majority of the soil samples show high available potassium. The soil of the Marathwada contained high to medium available potassium [18-22].

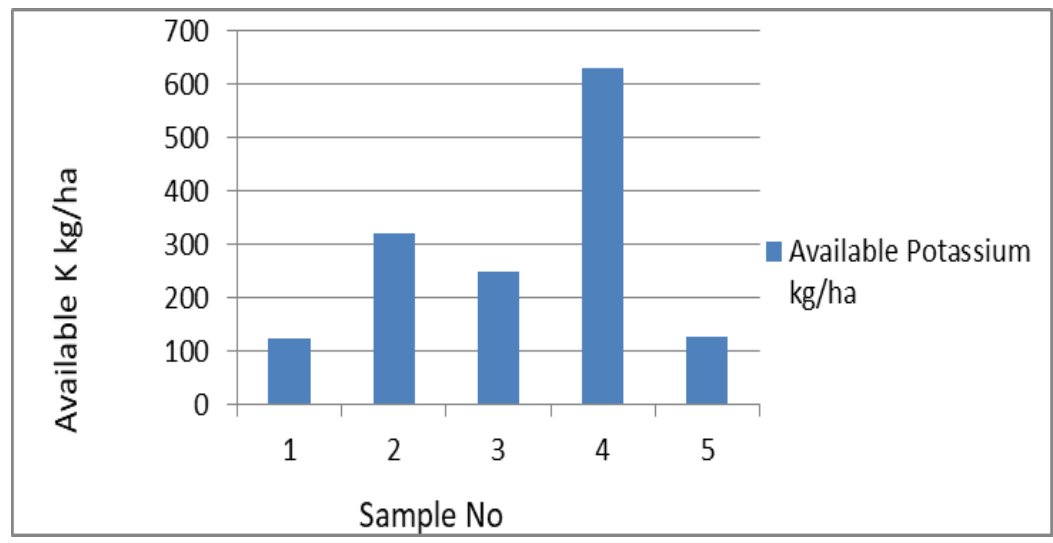

Figure 6Fertility Status of study area 


\section{Conclusion}

Conclusively from study area soil sample show medium proportion of organic carbon. The higher nutrient fertility status in irrigation fields might be associated with intensive cultivation and plantation of cash crops like sugarcane, cotton, fruit crops etc. in which use of fertilizers as practiced by the cultivators. Classification criteria the study area soils showed normal pH. The majority of soil samples low status of available phosphorous was found in all soil samples the generated nutrient status information can serve as an effective tool for farmers and policy makers in adoption of site specific nutrient management practices.

\section{Compliance with ethical standards}

\section{Acknowledgments}

We are very sincerely thankful to everyone who supported us. We are thankful for their moral support valuable guidance during this work. This work is for farmer related work so we devote this work to farmer and very glad to inform. I am very thankful of farmer those who help me and my college staff those who encourage me for this work.

\section{Disclosure of conflict of interest}

The author declare that there is no conflict of interest

\section{References}

[1] Agarwal RR and Gupta RN. (1968). Saline alkali soils in India. ICAR, Tech. Bull. (Agri. Series) No. 15, New Delhi, 1-65.

[2] Barhate CL. (1971). The physico-chemical properties of the soils of Ahmednagar district and the fertility status as influenced by agri-climatic differences, M.Sc. (Agri) dissertation, MPKV , Rahuri, Ahmednagar dist., Maharashtra.

[3] Bharambe PR and Ghonsikar CP. (1984). Fertility status of soils in Jayakwadi Command. J.Maharashtra agric. Univ, 9(3),326-327.

[4] Bharambe PR and Ghonsikar CP. (1985). Physico-chemical characteristics of soils in Jayakwadi Command. J. Maharashtra agric. Univ.10, 247-249.

[5] Bhattacharya T, Deshmukh SN and Roychaudhary C. (1989). Soils and land use of Junnar Tahasil, Pune district, Maharashtra. J. Maharashtra agric. Univ, 14(1),1-4.

[6] Biswas BC, Yadav DS and Maheshwari S. (1985). Role of calcium and magnesium in Indian agriculture. A Rev., ferti. News, 30, 15-35.

[7] Black CA. (1965). Method of soil analysis. Part 2 Inc. Publi; Madison, Wisconsin, USA.

[8] Chopra SL and Kanwar JS. (1991). Analytical agricultural Chemistry. Kalyani publi; New Delhi, Ludhiana.

[9] Dahama AK. (2002). Organic farming, on overview for sustainable agriculture. Second Enlarged Edition. Agrobios (India) Jodhpur.

[10] Daji JA. (1998). A textbook of Soil Science. Media promoters and publi. Bombay, 1-365.

[11] Gaibe MV, Lande MG and Varade SB. (1976). Soil of Marathwada. J. Maharashtra agric. Univ, 1(2-6),55-59.

[12] Hausenbuiller RL. (1976). Soil science, Principles and practices, Washington state University, Pullman,247.

[13] Hudson BD. (1994). Soil organic matter and available water capacity. Journal of Soil and Water Conservation 49(2), 189-194.

[14] Jackson ML. (1973). Soil chemical analysis. Prentice-Hall of India, New Delhi.

[15] Johnston AE. (1986). Soil organic matter, effects on soils and crops. Soil Use and Management, 2(3),97-105.

[16] Johnston AP, Poulton and K Coleman. (2008). Soil organic matter: Its importance in sustainable agriculture and carbon dioxide fluxes. Advances in Agronomy 101(November 30, 2008),1-57. 
[17] Kachhave KG and More SD. (1982). Research notes available potassium status in relation to physico-chemical properties of Maharashtra soils. J. Maharashtra agrci. Univ, 7(2), 1- 178.

[18] Miller RW and Donahue RL. (1992). Soils an introduction of soils and plant growth. 6th Edition prentic hall of India pvt. Ltd: New Delhi.

[19] Olsen SR, Cole CV, Watanbe FS and Dean LA. (1954). Estimation of available phosphorous in soil by extraction with sodium bicarbonate circ, U.S. Dept Agri, 939.

[20] Piper CS. (1966). Soil and plant analysis. Hans publi, Bombay.

[21] Richards LA. (1968). Diagnosis and improvement of saline and alkali soils. U.S. salinity Laboratory staff, Agriculture handbook No. 60, Oxford and IBH Publi. Co. New Delhi.

[22] Somwanshi RB, Kadu PP, Tamboli BD, Patil YM and Bhakare BD. (1999). Analysis of plants, irrigation water and soils MPKV. Extn. Publ. No. 284. Rahuri (Maharashtra).

[23] Subbiah BV and Asija GL.(1956). A rapid procedure for the determination of available nitrogen in soils. Curr. Sci. 25, 254-260. 